What constitutes sexual harassment and how should administrators handle it?

By: Katherine Cumings Mansfield, Amy Gray Beck, Kakim Fung, Marta Montiel, and Madeline Goldman

Mansfield, K.C., Beck, A.G., Fung, K., Montiel M., \& Goldman, M. (2017). What constitutes sexual harassment and how should administrators handle it? Journal of Cases in Educational Leadership 20(3), 37-55. https://doi.org/10.1177/1555458917696811

***@ 2017 The University Council for Educational Administration. Reprinted with permission. No further reproduction is authorized without written permission from SAGE. Reuse is restricted to non-commercial and no derivative uses. This version of the document is not the version of record. ***

\begin{abstract}
:
Gender discrimination and sexual harassment persist on college campuses across the United States. This seems especially obvious at the beginning of the academic year when many freshman women and their parents are welcomed to campus with sexually explicit signs displayed on all-male residences. But, sometimes, sexual harassment and gender discrimination takes a subtler form, creating unique challenges for administrators. This article presents the true case of a professional fraternity party gone awry, testing the leadership skills of several college administrators. The case provides a platform for educational leadership students to apply the theories they are learning in their preparation programs to real-life situations. This case is important and timely as educational leaders across the $\mathrm{p}-20$ pipeline struggle to navigate the U.S. Department of Education Office for Civil Rights' 2011 directives concerning defining and responding to allegations of sexual assault and harassment.
\end{abstract}

Keywords: Title IX | sexual harassment | gender discrimination | fraternity | hazing | ethics

\title{
Article:
}

In 1972, Title IX prohibited gender discrimination and sexual harassment in "all public and private elementary and secondary schools, school districts, colleges, and universities receiving any federal financial assistance" (U.S. Department of Education Office for Civil Rights [USDOE OCR], April 4, 2011). However, since its inception, there have been disagreements as to what constitutes "real" discrimination and harassment and how much evidence is necessary to have it recognized as such (Benokraitis \& Feagin, 1995). This has caused consternation for educational leaders, often leading to judicial intervention. Furthermore, there are different types of gender discrimination. Some are deliberate and visible, whereas others are subtler and more difficult to prove (Benokraitis \& Feagin, 1995). For example, an Inside Higher Ed article from August 28, 2015, decried the use of sexist banners that are all too commonly displayed on campuses across the United States:

The Old Dominion University chapter of Sigma Nu was suspended this week after members living in an off-campus house hung signs that many found offensive and sexist. 
"Rowdy and fun, hope your baby girl is ready for a good time," read one banner. Another advertised that the house was designated as the "freshman daughter drop-off" point, and a third sign added, "Go ahead and drop off Mom too." (New, 2015b)

And the situation at Old Dominion is not isolated or unique (New, 2015b). Jaschik (2015) and Kingkade (2015) would agree and add that in addition to being pervasive, the signs have gone unchallenged in most cases. For example, in the past 2 years, Bowling Green University, Georgia Southern, Ohio State, University of Michigan, Western Illinois University, and West Virginia University have come under fire for almost identical displays (Jaschik, 2015; Kingkade, 2015; New, 2015b). According to Jaschik (2015), Kingkade (2015), and New (2015b), numerous campuses across the United States have followed this "tradition" for years, even decades. Those who are offended by the practice have often used social media to post photos of the signs and communicate their displeasure. The general public has responded to online posts in a variety of ways, from fervent support for abolishing the practice to dismissing the "men's club" humor as excusable in light of the positive contributions fraternities make (Jaschik, 2015; Kingkade, 2015; Kirkland, 2016).

In addition to reporting sexist practices like the welcome to campus signs, reporters have also criticized sororities for perpetuating sexism. For example, Jake New of Inside Higher $E d$ (2015a) reported the everyday use of sexist and objectifying videos produced by sororities for marketing and recruiting, including hyper-sexualized scenes of bikini-clad sorority members running through bubbles and playing in a river. Similar to the signs posted by fraternities, the videos produced by sororities are not considered rare. Recent news points to their use at major universities like University of Alabama, Penn State, and University of Florida (New, 2015b). Although historically, the videos and other questionable communications have gone unchallenged, with the growth of social media, college administrators are finding themselves responding to community concerns by imposing sanctions (New, 2015b; Ole Miss, 2016).

But it is not just public displays of sexual discrimination that has caused consternation for college leadership: subtler forms of sexual harassment and gender discrimination on many campuses reflect that which occurs in general society. These seemingly ordinary practices, such as telling misogynistic jokes, unwelcome flirting, and using offensive vocabulary to designate people's supposed sexual preferences and/or gender identity often go unchallenged because so many in our society have internalized these acts as natural or tolerable (e.g., the outworn, "boys will be boys" excuse.) Moreover, it is difficult to prove whether less blatant forms of gender discrimination are innocent or malicious, intentional or unintentional; regardless, when people complain, they are often told they are too sensitive. Add to this, the most recent directives from the USDOE OCR that some say is an unlawful expansion of how institutions must define and respond to sexual assault and harassment (New, 2016).

This case is important and timely as educational leaders at all levels are currently struggling to navigate the most current USDOE OCR's rules, which leaves much to be desired in the clarity of the differences between guidance and mandates. Indeed, a group of 21 law professors claim in a formal statement that the OCR "needs to clarify which directives it considers to be guidance documents vs. regulations ... Directives that are deemed to be regulations need to be brought into compliance with requirements of the Administrative Procedure Act" (New, 2016). 
Meanwhile, a different group of 90 law professors defends the USDOE OCR's interpretation of, and consequent rules on, colleges' obligations under Title IX (Jaschik, 2016), to be explained in greater detail in the "Law and Policy Context" section.

This article presents a masked illustration, based on a true case in the southeastern United States. ${ }^{1}$ It is a story of a young woman bringing sexual discrimination and harassment charges against a member of a coed business fraternity, alleging she was verbally and physically degraded as part of an initiation event, testing the leadership skills of several college administrators. This case, and the accompanying activities, provides a platform for educational leadership students to apply the theories they are learning in their preparation programs to reallife situations. Students will also be positioned to know and understand the current controversies around the interpretation of USDOE OCR policy language and how it coalesces or diverges from the policy interpretations of, and implementation plans for, their particular organizational contexts.

\section{Description of the Case}

King Charles College (KCC) is a small private institution in the southeastern United States with a student body of 5,000. It is predominantly an undergraduate institution with a liberal arts focus situated in an affluent suburban neighborhood. The student population is predominantly White with males and females comprising $55 \%$ and $45 \%$ of the population, respectively. KCC relies heavily on its donors who contribute to its more than one-billion-dollar endowment. Fifty-five percent of the student population is affiliated with Greek organizations, with professional fraternities comprising $30 \%$ of the total student population. In addition, $\mathrm{KCC}$ was one of a few of its kind that had a coordinate college system. That is, the male and female students have a separate dean of students, in addition to other administrators, for each gender. For example, Wythe College houses the male students' administration and Astor College houses the female students' administration.

The case involves students from the School of Business, the dean of women students, Dr. Elizabeth Wilson, and the College President Dr. William Kade. Although there are other central characters, Dean Wilson and President Kade are the main protagonists, as they are at the center of the story, making the difficult choices and key decisions in this case. Before briefly describing the student body, we share some background on Dean Wilson and President Kade to better understand how their backgrounds and ways of thinking might contribute to their decision making.

\section{The Administration}

Dean Wilson studied business administration for her bachelor's degree and then took a job in the business offices at a small college in the Midwest. Dean Wilson quickly discovered the favorite part of her job was working with undergraduate students in financial aid, rather than "getting stuck" with duties in accounting where she had no direct contact with students. She especially enjoyed working with nontraditional female students who were single parents. While she worked

\footnotetext{
${ }^{1}$ This case is loosely based on an actual account. Descriptions of personalities and dialogue are fictional. Thus, we have chosen to use fictional names for people and places.
} 
her way up in the Financial Aid office, she took advantage of the tuition remission for faculty and staff and completed her master's in higher education with an emphasis in student development. She also took coursework in women and gender studies to help her better understand what she perceived as the unique needs of adult women. While attending a research conference, she was at the "right place at the right time" and was recruited to take a position as assistant director of student services in a small women's liberal arts college on the East Coast. While there, she attended a nearby Ivy League School, studying Higher Education Administration. She had big dreams for promotion, and indeed, completing the doctorate helped her do just that. She has been at KCC for 10 years - first as assistant dean, then as dean, of the women in Astor College. She loves her job, but finds herself getting progressively annoyed with what she identifies as "over privileged" students.

President Kade, on the contrary, could be described as one of those "over privileged" students. He was born into a very wealthy family who paid for an Ivy League education, including earning a JD at a highly esteemed Law School. While studying law, President Kade served as managing editor of a prestigious law journal and also served as a teaching assistant (TA) for the director of special programs, teaching students in the JD/PhD joint program of Law and Social Change. His family was somewhat disappointed that he did not go on to become a high-powered prosecuting attorney, followed by a career in politics like his father and grandfather before him. Rather, Kade chose higher education as a career and set his sights on becoming a president of a prestigious college one day. Kade's father made sure to call all the right people at every step of his son's career to make sure he was in the most powerful positions in the most highly esteemed private schools. Kade recently became president of KCC after serving as the Provost of a small, but prestigious all-male liberal arts college in England.

\section{The Students}

For the most part, business students come to KCC from wealthy and elite families in the southeastern United States. However, the school does reserve 10\% of admissions for "needy students." In the 1980s, only men enrolled in the business school. Some faculty and administration were concerned about this, but concluded that although women were "allowed" to go there, they must not be very interested in doing so. Under Dean Wilson's leadership, KCC has changed some of its recruiting strategies (e.g., holding informational sessions at all-girls' high schools) to attract more women into the business program. Dean Wilson has also worked with area school districts the past several years to establish "Future Women Business Leaders of America" groups across the region. An internal grant has afforded the expansion of this program by offering high school faculty a small stipend to lead a group at each location.

Today, the gender makeup of the KCC School of Business is $75 \%$ male and $25 \%$ female. The uneven distribution of male to female students has contributed to a culture that is often hostile to females. For example, it was not uncommon for male students to dominate class discussions and/or belittle contributions made by female students. Moreover, the women students often felt they were overlooked for important internship and externship opportunities in favor of their male counterparts. One brow-raising tradition in particular involves questionable male student behaviors but has been allowed to continue for decades despite prior complaints. The 
problematic custom involves a sexist-themed Greek initiation party that - besides a few minor complaints - most women do not seem to object to.

\section{The Incident}

As with decades past, plans for the new students' initiation into the business school were underway. For the past 20 years, the business school fraternity, Beta Sigma Omega $(\mathrm{B} \Sigma \Omega)$, has admitted women. Since then, this coed fraternity celebrates new initiates by hosting a party with the theme, "Sexy Secretaries and CEOs." To be inducted into the organization, the women are required to dress the part of the sexy secretary, while the men play the role of the CEO.

This year, Carrie, a new $\mathrm{B} \Sigma \Omega$ affiliate, was shocked to learn of the traditional theme for the induction party. At her high school, the principal and faculty were very sensitive to gender and sexuality issues and had implemented many new policies that aligned with the new USDOE Title IX guidelines. Sensitivity training was required of all entering freshman as well as students who moved into the school district later in their high school careers. Sexist jokes were not tolerated and anyone caught bullying someone based on their gender identity or sexual preferences were dealt with swiftly. Consequences sometimes involved suspension, depending on the seriousness of the issue, but always involved parent/caregiver conferences and additional sensitivity training, held on a Saturday in lieu of the typical out-of-school suspension (OSS).

Carrie expressed her discomfort with her two roommates, Jessica and Donna. Both Jessica and Donna expressed empathy for Carrie's concerns but encouraged her to put aside her discomforts in light of the professional contacts and other potential benefits that $\mathrm{B} \Sigma \Omega$ might provide. Donna said, "You know how this place is. Women may be allowed in (using air quotes), but, like, they're really not a part of the club, ya know what I mean?" Jessica added, "Yeah, and like, giving up this opportunity is only going to hurt your career. It won't change anything if you drop out." Carrie considered her roommates input and decided to go ahead and participate in the initiation party. She also chose to carefully select her "costume" so it was not too "over the top" as far as "sexiness" is concerned. She wore a pretty, but conservative, blouse, pencil skirt, and 2.5 inch heels.

She was welcomed to the party by Junior, Jonathan Owens, who was also one of the $\mathrm{B} \Sigma \Omega$ vice presidents (VPs). Carrie recognized Jonathan from the Rush parties she attended and felt honored that an upperclassmen and VP of the fraternity took the time to "show her around" and introduce her to her new brothers. However, it became readily apparent that the young men she met were disappointed in her lack of "sexiness" by their looks and whispers to each other. After about 15 min of introductions, Jonathan asked Carrie whether she had any questions. She said, "Yeah, I'm just wondering if everything is OK? I mean, I noticed the guys looking at me funny and whispering a lot. Did I do something wrong?" Jonathan laughed and said, "Well, you aren't exactly the sexiest secretary we've ever seen! I mean, look at that top! Show some cleavage, Bro!" Johnathan then reached over and unbuttoned her first two buttons. Carrie was mortified, but refrained from saying anything. She did not want to make waves.

Later that night, things started to get a bit out of hand. People were playing drinking games, and even got out the beer bong and gathered around new initiates shouting, "Chug, chug, chug!" The 
crowd began to thin as couples slipped out of the ballroom. Carrie was not one to judge, in fact she had a beer or two, but she just had a sick feeling inside telling her that it was time for her to leave. She walked over to the coat check, handed the attendant her ticket, and waited for her cashmere wrap. Jonathan startled her as he came up from behind her, put his hands on her shoulders, and whispered in her ear, "Where ya off to, sexy secretary? Don't leave now. This party's just getting started!" Carrie replied that she had a head ache and wanted to go back to her dorm, take an Advil, and go to bed. Jonathan put his arm around Carrie and said jovially, "I know a cure for what ails ya!" and then, he whispered, "I'll come put you to bed!" Jonathan laughed as Carrie rolled her eyes and reached for her wrap. "Good night," she said as she turned to walk away. Jonathan said, "Hey! Where ya goin? I said it's too early to leave!" and he grabbed her arm. It did not hurt and he was not yelling, but it still made Carrie very uncomfortable. She repeated, "Good night," pulled her arm away as gently as possible, so as to not cause a scene, and hurried to her dorm room. As she was leaving, Johnathan shouted after her, "Fine! Suit yourself! See how helpful I'm going to be to you now!"

The following Monday, Carrie complained to the dean of students, Dr. Wilson. She shared how she felt uncomfortable at the party and felt forced to wear revealing attire. She also shared that at one point she felt sexually harassed by Jonathan Owens (whose father is a major donor to the university). She shared a short version of the above exchange but made it clear that Jonathan had verbally "degraded" her.

On Wednesday, Dr. Wilson met with Jonathan. Jonathan expressed offense to the oversensitivity of Carrie, then shook his head while chuckling: "It was a joke! I was acting in theme of the costume." Dr. Wilson then asked Jonathan whether he had touched her or communicated in any type of threatening way. Jonathan rolled his eyes and said,

Oh, brother! What did she say? Did she say I hurt her? Did she say I groped her or something? I just barely touched her arm! It's not like I grabbed her butt or anything! Man! Girls can be so sensitive ...

Meanwhile, compromising photos of the themed party were posted to social media outlets. President Kade was briefed by public relations administrators about the questionable photos depicting women in revealing clothes and both men and women students holding what appeared to be alcoholic beverages. President Kade was disheartened about the media exposure but was not exactly sure how to approach and/or remedy the situation. The university had yet to develop and implement a policy on student and faculty social media use. Besides, President Kade was just 2 months into the position and was still learning institutional policy and how each of the administrative leaders worked together. Very quickly, he learned to rely on Dean Wilson for guidance in dealing with situations that involved the students. He called Dean Wilson and asked for a meeting right away. During the meeting, the President told Dean Wilson that he wanted her to develop a full plan of action to deal with the immediate problem and to keep him abreast of the situation as it unfolded.

Dean Wilson was troubled by a number of issues as she considered her next steps. She worried about possible ramifications if she took serious action against Jonathan, as Jonathan's father, Clyde Owens, is a major donor to the college and a member of the alumni board. Dean Wilson 
was also concerned about following students' due process rights. She also considered whether she or another administrator should make a statement to the press and/or student body. She could not help thinking that there must be something university administration could do that would be proactive rather than reactive concerning sexism and sexual harassment. She decided to sleep on it and take action in the morning.

$$
\sim \text { End of case }
$$

\section{Legal and Sociocultural Setting}

The purpose of this section is give the reader important background information before sharing the literature that comprises our blended theoretical framework. First, we explain the law and policy issues undergirding this case. Then, we consider the circumstances around Greek life on today's college campuses.

Law and Policy Context

Jeanne Clery Disclosure of Campus Security Policy and Campus Crime Statistics Act. The Clery Act is a consumer protection law passed in 1990 requiring colleges and universities that receive federal funding to report criminal activity (e.g., larceny, robbery, rape, murder) to the public. Specifically, it is a federal statute that is part of Title 34-Education, codified at 20 U.S.C. $\S 1092$ (f). In addition, the implementation regulations are located in the U.S. Code of Federal Regulations at 34 C.F.R. 668.46.

Although not a specific component in Title IX, The Cleary Act is certainly related when there has been a criminal charge of sexual assault or domestic violence, for example. In addition to making crime statistics publicly available, The Cleary Act also demands that institutions provide survivors of criminal behavior with support such as notifying local law enforcement and providing options for academic or living situations. In addition, educational organizations are required to provide both the plaintiff and defendant certain rights to due process in the campus disciplinary process. Finally, colleges and universities must have specific policies and procedures related to disseminating emergency notifications after a crime has been reported (see http://clerycenter.org, for additional information).

Title IX. According to the USDOE OCR,

Title IX of the Education Amendments of 1972 (Title IX), 20 U.S.C. $\S \S 1681$ et seq., and its implementing regulations, 34 C.F.R. Part 106, prohibit discrimination on the basis of sex in education programs or activities operated by recipients of Federal financial assistance. (Ali, 2011)

Under Title IX, all levels of the p-20 pipeline are included from elementary to secondary to postsecondary schooling contexts.

In 2011, the USDOE OCR provided additional technical assistance to schools in achieving voluntary compliance with Title IX in the form of a "Dear Colleague Letter," a full technical 
report, and three additional informational papers designed to inform both administrators and students across all educational contexts (see the online appendices for these documents).

As mentioned prior, there are two major groups of law professors who have issued open letters in response to the USDOE's rules on college's obligations under Title IX specific to sexual assault. The major distinction between the groups centers around the standards needed to adjudicate discrimination claims. One view backs the USDOE's directive to use a "preponderance of evidence" standard rather than a "beyond reasonable doubt" standard. The reasoning behind this is that other civil rights statutes such as Title VI (prohibiting race discrimination by educational institutions) and Title VII (prohibiting racial and sexual discrimination in employment, including sexual harassment on the job) adhere to the former; thus, it makes sense that Title IX follows suit. Whereas the USDOE reasons the 2011 instructions simply clarify existing law, others contend the USDOE has unlawfully expanded how educational organizations must define and respond to allegations of sexual harassment and assault (Jaschik, 2016; New, 2016).

Greek Life on Campus Today

Students at the tertiary level have extensive opportunities to become involved with Greek life. Most colleges and universities host a combination of social sororities and fraternities, professional fraternities, and discipline-specific societies. Whereas social sororities only accept women and social fraternities only accept men, many professional fraternities and disciplinespecific societies are gender integrated. However, not all professional Greek organizations are coed (Neff, 2012). For example, Phi Mu Alpha is all male and Sigma Alpha Iota is all female. Kappa Kappa Psi is also all male and their "sister counterpart" is Tau Beta Sigma.

Over the years, distinctions between social and professional Greek organizations have blurred considerably vis-à-vis the balance between social activities and professional development (Meyer, 2013; Neff, 2012; Oglesby, 2013). Generally speaking, the purpose of social Greek groups is to develop oneself and character through service and social activities. Whereas, professional Greek groups usually center on a common major or shared career interest and aim to prepare students in their transition from school to the job market (Meyer, 2013; Neff, 2012). However, it is now common for professional fraternities to partake in social activities and social fraternities to participate in professional activities.

Most Greek groups, whether social or professional, have similar recruitment or rush activities. This is followed by a period of intense learning by the Pledges, culminating with unique rituals designating Pledges as Actives (Meyer, 2013; Neff, 2012; Oglesby, 2013). Although not all Greek groups are guilty of hazing, all types are bound by rules prohibiting hazing (Meyer, 2013; Neff, 2012; Oglesby, 2013). Moreover, hazing infractions have been reported by both social and professional fraternities in addition to discipline-specific societies. (Just one example is Kappa Kappa Psi, a coed music fraternity at University of Arizona, which has been investigated for a history of serious hazing infractions [Tucson News Now, 2015].) According to Neff (2012), the biggest difference between professional and social Greek organizations is the level of media scrutiny endured by social sororities and fraternities. And the bottom line is: All sororities and fraternities, whether social or professional, have their "distinct culture" (p. 1). 
As an active part of campus life, social and professional fraternities and sororities contribute positively to the community. For example, almost all Greek organizations have adopted one national charity for their primary philanthropic undertaking. In addition, many sororities and fraternities contribute to their regional and local communities by participating in activities such as walks for breast cancer, food collection for city pantries, and volunteering for Special Olympics. Specific examples include Pi Kappa Phi (ПКФ) fraternity who sponsors The Ability Experience, formerly known as Push America (Pi Kappa Phi, n.d.; The Ability Experience, n.d.), and Delta Zeta $(\Delta \mathrm{Z})$ sorority who partners with the Starkey Hearing Foundation and Gallaudet University as part of their speech and hearing philanthropic commitments (Delta Zeta, n.d.).

Although there are studies that document the benefits of Greek life in terms of academic performance and student leadership, there are troublesome concerns which involve the social behavior of affiliated students. For example, Greek groups, especially fraternities, emphasize gender conformity and organizational uniformity. Moreover, male college students are more likely to lack awareness of gender issues than their female counterparts. In addition, males are often taught to avoid "femininity" and to be the aggressors in relationships (Kuh \& Jelke, 2003). Relatedly, Murnen and Kohlman (2007) conducted a meta-analysis of 15 studies of diverse college campuses across the United States that suggested a strong association between fraternity membership and perpetration of sexual aggression. In an older study, Koss and Gaines (1993) used the Hostility Toward Women Scale to determine that fraternity members reported a higher degree of hostility toward women than did their non-Greek counterparts. In addition, Minow and Einolf (2009) found that sorority women report they were sexually assaulted four times more often than nonsorority members.

Thus, while it is fair-minded to recognize the positive aspects of social and professional Greek membership, it is also important to acknowledge there are characteristics that make members of these groups more vulnerable to social misconduct. In the case we present here, there are many factors that play a role and equally many theories that attempt to explain the propensity for members of sororities and fraternities to perpetuate collective misbehavior. For this study, we draw on a combination of frameworks: student development theory, constructive-developmental theory, leadership ethics, and situational leadership theory to be described next.

\section{Associated Literature Undergirding the Case}

Incidents of sexual harassment on college campuses is a complicated matter that calls for consideration of applicable federal laws, state and local policies, and contextual complexities specific to each organization. In response, educational administrators are called upon to make decisions that are in the best interests of students while also obeying related laws and policies. Likewise, in reaction to the complexity of the issues described in this case, administrators must draw on a variety of frameworks to aid in decision making. Our blended theoretical framework proposes using student development theory to consider how students engage in learning in a university setting. In addition, we believe keeping in mind constructivist-developmental theory will allow educational leaders to reflect on the means by which people respond to social environments. We also offer a discussion on leadership ethics and situational leadership theory as a means to examine the nuances that pertain to situations specific to this case. 


\section{Student Development Theory}

The student services field developed as a result of the need to regulate student behavior (Decker, 2013). Student services professionals have incorporated student development theory to help students achieve their life and career goals. The belief is that the university learning environment goes beyond the classroom to include all student interactions (Decker, 2013). Thus, these student development theories can be used to inform all aspects of university life.

William Perry's (1970) theory of student development is based on Piaget's cognitive development theory (Love \& Guthrie, 1999). Perry's theory asserts that as students progress through stages of development, their thinking changes in addition to their sense of self and their view of the world around them (Knefelkamp, 2013). Accordingly, there are four major developmental stages through which the student progresses:

1. Dualism, which entails two substages. First, people develop an understanding of truth in absolute terms, identified with obeying an authority figure such as a parent, teacher, or religious doctrine. Second, people begin to recognize that a variety of perspectives exist; however, the individual continues to see their point of view as correct and views others' beliefs as wrong. Thus, all concepts, behaviors, and people can be separated into two categories: I/we/right versus he or she/they/wrong.

2. Multiplicity, which involves modifying one's perspective from right-wrong dualism to acknowledging diversity in human thought. In this stage, people acknowledge uncertainty in the world, but hold onto their dualism perspective by adding a third standpoint: not yet known. Thus, that which is knowable is either good or bad and that which is unknown can become known over time, and eventually labeled good or bad. Students in this stage of development have the perspective that one can never know for sure what is right or wrong; thus, "anything goes."

3. Relativism, whereby people move from viewing the world in either/or terms to that of the inclusive "and." This transition is significant in that people move from viewing the world as basically dualistic with a collection of exceptions, to understanding ethics as contextual and something that is actively constructed by individuals. This stage is more intellectual than ethical in that students recognize that any act of knowing (thinking, talking, reading, and writing) requires each individual to adopt a point of view. In this stage, students recognize their positionality in relation to others.

4. Commitment within relativism, which is exhibited by shifting emphases from intellectual understandings to active, ethical commitments after carefully considering the plethora of alternatives. The student moves from experiencing genuine doubt to discovering and/or affirming one's identity within and a part of a contextual world. This stage is iterative in that the individual continues to refine their ethical commitments as they relate to others and to the world. Very few undergraduate students have reached this stage of ethical development as it requires substantial time and effort.

With these constructs in mind, it is important to recognize all students along the $\mathrm{p}-20$ pipeline are unique and most likely move through these distinctive stages differently. Moreover, cultural perspectives and values influence each student as they move toward a more independent way of thinking. 
Constructivist-Developmental Theory

Kegan's (1994) work on student development builds on the foundations laid by Perry, but also asks us to view student development more holistically. In addition, Kegan extends Piaget's theory of development beyond adolescence. Bista and Foster (2016) described Kegan's theory as a constructivist-developmental theory that focuses on student meaning-making in a variety of dimensions:

1. The epistemological dimension: a cognitive process, which entails absolute knowing, transitional knowing, independent knowing, and contextual knowing.

2. The intrapersonal dimension, which involves understanding one's own beliefs and values and answers the question, "Who am I?"

3. The interpersonal dimension (most associated with childhood development), in which others' perspectives serve individual egocentric needs. Moreover, during adolescence, peers' perspectives usually become paramount; especially, when youth become part of a larger community and coconstruct mores with others (King \& Baxter Magolda, 2011). In this third order, we are the subject of these coconstructions and lack skills to exist outside of them for reflection. We believe what others think we should believe, and thus, create identities we think others want from us. We seek approval in relationships and are consumed by other's perceptions.

4. In contrast, the fourth order describes the movement toward self-authored meaning making with an internal authority that manages the conflicts and contradictions that exist in life. Similar to Perry's commitment to relativism, the transition from socializing to self-authorship can be a slow process. This dimension is referred to as the system/institutional order.

Although it is important for educational leaders at all levels to understand these theories of development holistically, the third and fourth order are most applicable to college students (King \& Baxter Magolda, 2011) and thus, this case.

The main argument behind Kegan's theories is the importance of providing students an environment that acknowledges people where they are right now, is both supportive and challenging, and fosters the students' psychological evolution via nonjudgmental guidance (Traylor, 2010). King and Baxter Magolda (2011) further elaborated on Kegan's self-evolution theory as it pertains to college students: As the internal voice develops, the external voice gradually subsides until the internal voice is able to manage external influences (ASHE Higher Education Report, 2012). In other words, between the external and internal stage is a type of crossroads that is a mixture of external and internal orientations. Thus, students who are unable to author their psychological lives may be overly influenced by external forces, potentially damaging their academic goals and relationships (ASHE Higher Education Report, 2012).

Leadership Ethics

D. Solomon (2008) defined ethics as "a rational reflection on human conduct with the aim of directing that conduct in appropriate ways" (p. 4). Koterski (2002) provided a similar 
definition-For him, "ethics is an attempt to systematize and reflect theoretically about questions of morality" (p. 24). Previously, R. C. Solomon (1989) had defined ethics as the study of morality by stating the following questions: "What should we do? What should we not do? What acts should we praise? What acts should we condemn and blame? These are questions of ethics, the concern for which made Socrates willing to give up his life" (p. 539). Similar questions confront educational leaders in both higher education and the K-12 arenas.

According to Treviño, Hartman, and Brown (2000), ethical leadership implies making the best decisions based on what is right when one is in a powerful position. It is common that educational leaders are placed in positions in which they have to face dilemmas and make difficult decisions that require strong ethical foundations. Kaufman (2008) defined what ethics should look like in educational settings and urged leaders at all levels to consider this definition in their daily activities:

Ethics in education is based on decisions and actions that lead to a situation where all citizens survive and have a positive quality of life. It is the responsibility of every citizen and every organization, public and private, to add value to all other citizens and residents of our shared world. Thus, ethics is what leads to decisions that guide us to the measurable value added for all stakeholders. (p. 11)

In other words, educational leaders are responsible to ensure that every single person within the organization is respected, feels safe, and experiences a good quality of life in the organization; thus, all leadership decisions should be made in regard to this premise. It is the responsibility of an educational leader to promote the safety and well-being of all members within a campus inasmuch as in their control in many different situations and circumstances. And this requires that leaders respond to situations differently depending on the situation.

\section{Situational Leadership Theory}

Situational Leadership Theory, developed by Ken Blanchard and Paul Hersey in 1969, proposes that good leadership is orchestrated when an individual understands a situation and responds appropriately, rather than relying on charisma. McClesky (2014) offered,

Situational leadership in general and Situational Leadership Theory (SLT) in particular evolved from a task-oriented versus people-oriented leadership continuum. The continuum represented the extent that the leader focuses on the required tasks or focuses on their relations with their followers. (p. 118)

Another words, if you can visualize leadership on a continuum, individuals who are task-oriented (on one side of the continuum) prefer to use definitive rules and policies, give followers specific roles, and prefer to use formal communication patterns and channels (Hersey \& Blanchard, 1969). On the other side of the continuum are those who prefer to rely on-and make decisions based on-relationships with individuals. Rather than strictly "going by the book," these individuals may base their decisions on that which reduces conflicts, ensures all people are heard equally, and provides the most harmony for all (Hersey \& Blanchard, 1969). People may fall 
naturally to one side or the other, but a healthy mix of both, depending on the situation, is best for effective leadership.

\section{Teaching Notes}

Using the case study provided, have students first answer discussion questions in a large group to have them begin to think about the theories that were used or not used in leadership decision making. Encourage students to identify what is specifically missing in terms of leadership policy and practice in this particular case study, and in what ways taking time to consider theory might be helpful to leadership decision making. Thereafter, move along to the small group activity.

\section{Large Group Discussion Questions}

Place yourself in both President Kade's and Dean Wilson's positions and discuss the following:

1. As there is currently no written policy on social media use, what would you do first?

2. How would you handle an inbox of emails from a variety of constituents such as parents, the student body president, and the media? In what order might you respond?

3. How would you have addressed the female student's concerns about harassment?

4. What do you think should happen to the male student?

5. How would you handle Dr. Owens, the important donor?

6. What other stakeholders would you involve in the above scenarios? Why?

7. How does student development theory inform your decisions?

8. How does leadership theory inform your decisions?

Alternatives. We have found that these types of large group discussion questions work well with online discussion boards. In addition, the discussion questions could be used as prompts for formative evaluation essays. They also could be used as prompts to develop a longer course paper focused on ethical decision-making, law, and/or policy and planning.

\section{Small Group Activities}

The small group activities can be adapted depending on the nature of the course in which this case is used. For example, in addition to facilitating small group work during class, they could also be used in online or hybrid courses to get students collaborating and working together.

Option 1. Have two students write a script for a role-play that details a conversation between Dean Wilson and Dr. Owens. Make sure to utilize the continuum of situational theory as well as ethics in the scenario. This script would lead to a production of the role-play during class time as a required assignment. Also, use direct references to Title IX for support. It is suggested to include disagreement between the parties on what the new regulations of Title IX actually require them to do and how they plan to solve this disagreement.

Alternative. This meaning-making activity is easily adapted to the K-12 setting. For example, students can create a scenario that involves a principal and parent-teacher association (PTA) president or superintendent and school board president. The district superintendent could take the 
place of President Kade, Dean Wilson might be represented by the school superintendent, and the PTA president might be the parent of a male student who has sexually harassed a female student on the bus ride home from school.

Option 2. Have students work in pairs to produce a story board that would be the foundation for a training video to be shown to the campus community. The script would form the foundation of creating a video to be presented to the class as a required assignment. The parameters of the video are the following:

1. It cannot be more than 3 min in length;

2. It must refer to associated sections of new Title IX regulations;

3. It must include at least three examples of "subtle" forms of sexual harassment and gender discrimination; and

4. It must communicate that sexual harassment and gender discrimination will not be tolerated at KCC.

Alternative. This meaning-making activity is easily adapted to the K-12 setting. For example, students might choose to feature an imaginary superintendent speaking to all students, staff, faculty, and parents about behavioral expectations and consequences. Or, the students might choose to make a video specific to their school or other professional situation. Perhaps there have been similar cases in their elementary, secondary, or tertiary organization where students have taken the lead to produce posters, flyers, and or social media messages that address bullying queer students.

\section{Individual Long-Term Project}

Option 3. Develop a detailed roll-out plan for changing the culture of discrimination of all forms at KCC. Consider all stakeholders, student development theory, and timeline. Use direct references to Title IX for support, along with other resources found in the online appendices. Consider the following questions as you plan out your project:

1. What steps need to be taken to help change the gender-privilege culture of the university at large? Who should be involved? Why?

2. What steps need to be taken to change the culture of the fraternity? Who should be involved? Why?

Alternative. This meaning-making activity is easily adapted to the K-12 setting, as schools and districts are also struggling with how to interpret and enact new Title IX guidelines and need to address these changes effectively. For example, after conducting an equity audit around gender gaps in the maths and sciences, students might examine existing policy around Title IX expectations, infractions, and responses. Then, students in K-12 settings might develop a framework for addressing gender discrimination in their particular settings. In addition to considering child and youth development theory, they might consider the following questions as they plan out their project: 
1. What steps need to be taken to alleviate the disproportionality between male and female students in advanced math/science classes?

2. Who should be involved with the development and implementation of this plan? Why?

Option 4. Each student researches policies related to sexual harassment in their home institutions (throughout the PK-20 spectrum). The purpose of this assignment is for all leadership students to know and understand Title IX policy statements as well as the most recent USDOE guidelines that have caused controversy among legal scholars and some educational administrators. The following statements and questions might be used to guide students' prewriting reflections:

1. How does your organizational policy communicate provisions under Title IX?

2. How closely does your organization's policy language "match" the language of the actual Title IX policy language?

3. What are the due process procedures in your organization?

4. Does your organization include the latest USDOE OCR policy language? If so, how do the OCR guidelines translate into on the ground realities? For example, does your organization use a "preponderance of evidence" standard or the "beyond reasonable doubt" standard in determining whether sexual harassment has taken place?

5. What are the consequences for sexual harassment perpetrated by faculty, administration, and or staff? What are the consequences for sexual harassment perpetrated by students?

6. Does your organization outline appropriate supports for survivors of sexual assault as outlined in the Cleary Act?

7. Does your organization have a policy for communicating Title IX infringements to the public as the Cleary Act requires?

8. How might the contextual complexities of your particular organization have influenced development and implementation of Title IX and the Cleary Act? For example, some educational institutions use social media, such as texting and email, to communicate Title IX policy infringements.

Authors' Note. This case study, the teaching notes, and the corresponding activities are suitable for any college-level educational leadership class that integrates leadership theory, professional ethics, educational policy and law, and/or concepts of leadership for social justice within its content.

Declaration of Conflicting Interests. The author(s) declared no potential conflicts of interest with respect to the research, authorship, and/or publication of this article.

Funding. The author(s) received no financial support for the research, authorship, and/or publication of this article.

\section{Supplemental Material}

The supplemental materials are available at http://journals.sagepub.com/doi/suppl/10.1177/1555458917696811.

\section{References}


Ali, R. (2011). Dear Colleague Letter: Office of the Assistant Secretary. Available at: https://www2.ed.gov/print/about/offices/list/ocr/letters/colleague-201104.html

The Ability Experience . (n.d.). A Pi Kappa Phi philanthropy. Available from http://www.abilityexperience.org

ASHE Higher Education Report . (2012). Nudging minds to life: Self-authorship as a foundation for learning ASHE Higher Education Report, 38, 1-19.

Benokraitis, N. V., Feagin, J. R. (1995). Modern sexism: Blatant, subtle, and covert discrimination. Englewood Cliffs, NJ: Prentice Hall.

Bista, K., Foster, C. (Eds.). (2016). Campus support services, programs, and policies for international students. Hershey, PA: IGI Global. doi:10.4018/978-1-4666-9752-2

Decker, A. (2013). Student centered practice in the 21 st century community college. Community College Journal of Research and Practice, 37, 561-565.

Delta Zeta . (n.d.). Speech and hearing. Retrieved from http://www.deltazeta.org/philanthropy/speechandhearing

Hersey, P., Blanchard, K. H. (1969). Life cycle theory of leadership. Training \& Development Journal, 23, 26.

Jaschik, S. (2015, August 25). Sexist "welcome" banners at Ohio State. Inside Higher Ed. Retrieved from https://www.insidehighered.com/print/quicktakes/2015/08/25/sexistwelcome-banners-ohio-state? width $=775 \&$; height $=500 \&$ iframe $=$ true

Jaschik, S. (2016, May 17). Law professors defend education dept. on burden of proof. Inside Higher Ed. Retrieved from https://www.insidehighered.com/print/quicktakes/2016/08/08/law-prof.efend-educationdept-burden-proof?width $=775 \& ;$ height $=500 \&$ iframe $=$ true

Kaufman, R. (2008, Summer). A practical definition of ethics for truly strategic planning in higher education. New Directions for Higher Education, 2008, 9-15.

Kegan, R. (1994). In our heads: The mental demands of modern life. Cambridge, MA: Harvard University Press.

King, P. M., Baxter Magolda, M. B. (2011). Student learning in student services: A handbook for the profession. San Francisco, CA: Jossey Bass.

Kingkade, T. (2015, August 25). It's not just ODU students putting up offensive signs about freshman girls: All the other banners make pretty much the same joke. The Huffington Post. Retrieved from http://www.huffingtonpost.com/entry/odu-fraternity-freshman-girlsbanners us 55dbd2d8e4b0a40aa3ac00ba

Kirkland, L. (2016, April 18). Allegations of "sexual harassment" at a fraternity event continue. The Daily Mississippian. Retrieved from http://thedmonline.com/copy-chief-ole-missfraternity-philanthropy-generates-investigations-controversy/

Knefelkamp, L. L. (2003). The influence of a classic. Liberal Education, 89, 10-15. 
Koss, M. P., Gaines, J. A. (1993). The prediction of sexual aggression by alcohol use, athletic participation, and fraternity affiliation. Journal of Interpersonal Violence, 8, 94-108.

Koterski, J. (2002). Lecture transcript and course guidebook: Natural law and human nature. Chantilly, VA: The Teaching Company.

Kuh, G. D., Jelke, T. (2003). High performing fraternities and sororities. In Gregory, D. E. (Ed.), The administration of fraternal organizations on North American Campuses (pp. 280291). Asheville, NC: College Administration Publications.

Love, P. G., Guthrie, V. L. (1999). Perry's intellectual scheme. New Directions for Student Services, 88, 5-15.

McClesky, J. A. (2014). Situational, transformational, and transactional leadership and leadership development. Journal of Business Studies Quarterly, 5, 117-130.

Meyer, M. (2013, March). Social versus professional fraternities. The Times-Delphic. Retrieved from http://timesdelphic.com/2013/03/28/social-versus-professional-fraternities

Minow, J. C., Einolf, C. J. (2009). Sorority participation and sexual assault risk. Against Women, $15,835-851$.

Murnen, S. K., Kohlman, M. H. (2007). Athletic participation, fraternity membership, and sexual aggression among college men: A meta-analytic review. Sex Roles, 57, 145-157.

Neff, J. (2012, August). Professional versus social Greek organizations. Indiana Statesman. Retrieved from http://www.isustudentmedia.com/indiana_statesman/

New, J. (2015a, August 19). Sorority chapter under fire for recruitment video. Inside Higher Ed. Retrieved from https://www.insidehighered.com/print/news/2015/08/19/sorority-chapterunder-fire-recruitment-video?width $=775 \&$; height $=500 \&$ iframe $=$ true

New, J. (2015b, August 28). Sexist banners at Old Dominion point to a practice at many campuses. Inside Higher Ed. Retrieved from https://www.insidehighered.com/print/news/2015/08/28/sexist-banners-old-dominionpoint-practice-many-campuses? width $=775 \&$; height $=500 \&$ iframe $=$ true

New, J. (2016, May 17). Professors urge Department of Education to revise sexual assault guidance. Inside Higher Ed. Retrieved from https://www.insidehighered.com/news/2016/05/17/professors-urge-departmenteducation-revise-sexual-assault-guidance

Oglesby, M. (2013, September). Business vs. social fraternities. The Trinitonian. Retrieved from http://www.trinitonian.com/business-vs-social-fraternities/

Ole Miss . (2016, April 16). Statement regarding allegations of unacceptable behavior at Derby Days event. University of Mississippi News. Retrieved from http://news.olemiss.edu/statement-regarding-allegations-unacceptable-behavior-derbydays-event/

Perry, W. (1970). Forms of intellectual and ethical development during the college years. New York, NY: Holt, Rinehart and Winston. 
Pi Kappa Phi . (n.d.). Exceptional leaders. Uncommon opportunities. Available from http://pikapp.org

Solomon, D. (2008). Twentieth-century ethics. Retrieved from http://icucourses.com/products/twentieth-century-ethics

Solomon, R. C. (1989). Introducing philosophy. Chicago, IL: Harcourt Brace Jovanovich.

Traylor, J. (2010). Robert Kegan's constructive developmental theory: Orders of consciousness [SlideShare]. Retrieved from http://www.slideshare.net/JessicaTraylor/keganconstructive-developmental-theory

Treviño, L. K., Hartman, L. P., Brown, M. (2000). Moral person and moral manager: How executives develop a reputation for ethical leadership. California Management Review, $42,128-142$.

Tucson News Now . (2015, March). UA's music fraternity accused of hazing. Retrieved from http://www.tucsonnewsnow.com/story/28254629/ua-music-fraternitys-charter-revokedamid-hazing-accusations

U.S. Department of Education Office for Civil Rights [USDOE OCR] . (April 4, 2011). Dear Colleague Letter: Sexual Violence Background, Summary, and Fast Facts. Available at: https://www2.ed.gov/about/offices/list/ocr/docs/dcl-factsheet-201104.html

\section{Author Biographies}

Katherine Cumings Mansfield ( $\mathrm{PhD}$, The University of Texas at Austin) is an assistant professor at Virginia Commonwealth University where she enjoys teaching an array of courses such as Program Evaluation Theory and Methods, Critical Policy Analysis, School-Community Relations, and Leadership for Social Justice and Equity. A first-generation college graduate and seasoned K-12 educator, Mansfield is an award-winning researcher and teacher, garnering two dissertation awards from the American Educational Research Association in 2012, the VCU Excellence in Teaching Award in 2014, and the VCU School of Education Distinguished Junior Faculty Award in 2016. Katherine is a proud Delta Zeta and Pi Kappa Phi Little Sis.

Amy Gray Beck is a PhD candidate in the Educational Leadership Department at Virginia Commonwealth University. Her professional interests and experience revolve around student development, university advancement, and alumni loyalty. Gray Beck is currently the senior director for Outreach and Engagement in Alumni Relations at VCU. Amy is a proud Kappa Delta.

Kakim Fung is currently pursuing both a PhD in Educational Leadership and a second Master's in the Department of Mathematics and Applied Mathematics at Virginia Commonwealth University. Mr. Fung is in his second year of teaching mathematics at the secondary level. After completing his current studies, he hopes to teach computer science, mathematics, and educational ethics and politics at the college level. 
Marta Montiel is a PhD candidate in the Educational Leadership Department at Virginia Commonwealth University. Ms. Montiel has been working in the educational field for more than 20 years. She is currently a full professor and the academic coordinator of the Language Center at Universidad El Bosque in Bogotá, Colombia.

Madeline Goldman is a PhD candidate in Urban Services Leadership (Adult Learning) at VCU. Her dissertation explores the role of learning experiences, supports, and barriers in career development for the graduate student. She is currently a career counselor in the VCU School of Business. Madeline is a proud Zeta Tau Alpha. 